\title{
Emigration, Family and Kinship
}

By

Sune Åkerman, Bo Kronborg and Thomas Nilsson, University of Uppsala

\section{Introduction}

Comparatively little research has been devoted to the study of individuals and groups of individuals in a demographic context. This is, of course, a consequence of the scarcity of sources which most scholars, and especially historians, have to face. It could be added that statistically inclined population research has generally avoided human-centered studies as well as investigations which try to include economic as well as social and cultural dimensions into a broader kind of analysis. Even those scholars who have been aware of the importance of contacts between individuals for the extent, structure and direction of human migrations have been unable to perform such studies for practical reasons. ${ }^{1}$

If we were to point out some especially neglected areas of research within the study of migration it would be the internal movements within countries and particularly the mobility that takes place within smaller administrative units, which usually form the basis of the statistics. Such short distance movements will almost never be registered, although they often tend to be very extensive.

A study of mass emigration as a process will soon reveal especially if performed in a longitudinal context - that there has been a kind of self-generating effect, which can be isolated from external influences. It is easy to suggest that there may be a connection between this self-generation and the contacts on an individual level. A connection may also exist with the established interplay between well-defined areas in the delivering as well as the receiving countries.

This is the theme of our present article. 


\section{Area of Investigation. The Source Material}

For reasons of documentation (source coverage) our study must be confined to Finland and Sweden. If we choose Sweden for our investigation then the southwestern parts of the country will be the most suitable because of the strong regional concentration of emigrants. Our interest has been focused on the classical emigration region of southern Småland (see Figure 1), and within it on the little parish of Långasjö.

Our choice has been guided by the fact that strong local interest in investigating the mass emigration period has existed for many years in Långasjö. In fact, a group of local historians have published a popular book dealing with emigration. This substantial volume treats different aspects of the exodus from the home parish and acts as a landmark for similar studies. The "Långasjö book" has enabled us to treat a considerable amount of information which otherwise would have been outside the range of academic research. ${ }^{2}$

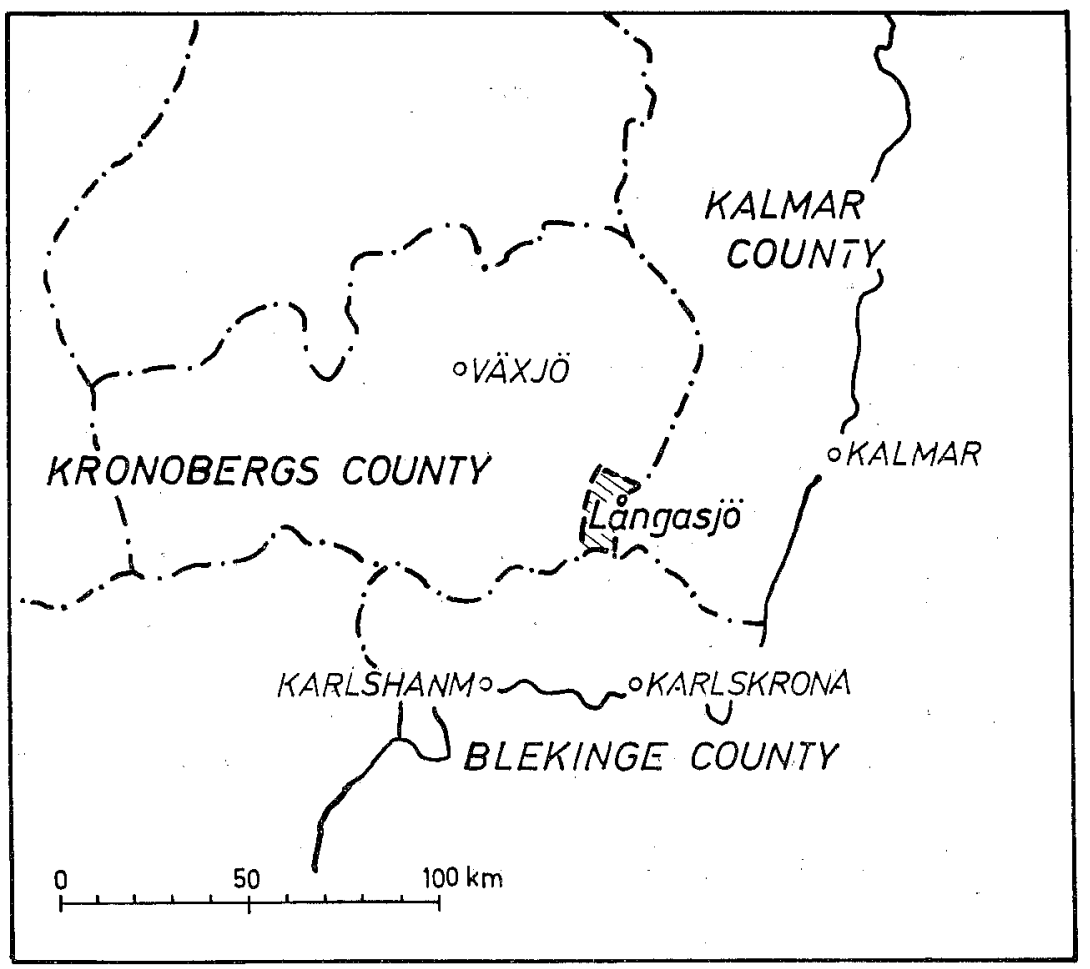

Figure 1. The investigation area. 
Among other things, the oral tradition was tapped rather systematically. Thus the Långasjö historians were able to interview many parishioners who had participated in the emigration, as well as others who knew about the migrants and the conditions which forced people to leave the country. Very important information was furnished by a group of re-migrants who possessed knowledge about the whole process of the trans-oceanic movement.

Like the Långasjö historians, we use the church archives as the central source; as is well known, this material acts as a small information system of the population in every parish. Its main and basic feature is the continuous registration of all vital events. In addition to other similar registers found both in Lutheran and Catholic countries, there are - at least since the late 17 th century or early 18th - special examination records (husförhörslängder) where every household and family are registered separately. These examination records are unique sources of the demographic information in Sweden and Finland and act as an axis around which all other sources revolve. Without these records we would have been unable to conduct this detailed study. ${ }^{3}$

As a matter of fact, the choice of one area or another for our study is of minor importance since our aim is to shed light on general human behavior and reactions. Hence personal contacts as well as family and kinship ties must be supposed to have an impact irrespective of the economic conditions of a certain area. Nevertheless, a short survey of the situation in Långasjö parish at the start of the mass emigration will be given.

Långasjö parish, which was a community of small peasants, is situated in a part of southern Sweden, which was very different from the fertile agricultural region of the southernmost province of the country, Scania. Bare and stony soils, remnants from the glacial period, were dorninant. The countryside was extensively covered with forests, and was more suited for cattle breeding and subsidiary rural activities than arable agriculture in a stricter sense of the word. But against the odds the people of this barren region had tried for centuries to get a living out of the poor soils and the small patches of land between blocks of stone, small lakes and swamps. This "battle against the stones" has been depicted in several of the masterpieces by the novelist VilheIm Moberg, who describes how the stone walls enclosing the small fields tell a story of human endurance close to the subsistence level.

For the small family farms in the area a crop failure was something 
very serious and two consecutive failures meant catastrophe. This situation occurred in 1867 and 1868 and can hardly be described better or with greater compassion than in the journal kept by Sven Samuelsson, who lived in the neighbouring parish of Ljuder. His journal mostly records the daily life of the district but also tells us about the severe drought during the summer and fall of 1868:

"The drought has now reached the stage when grass wilts, and crops run great risks of being reduced to nothing." (June 1868).

"The drought continues, the grass has wilted, in some places trees stand dead with leaves that have dried up and even fallen off." (June 1868).

" The drought continues with fearful strength, conversation concerns the crops and the consequences of the crop failure that is now (to be expected).'" (July 1868).

"The drought continues with severe heat, the rye is turning white and the soil is scorched with all that grows on it, work is unbearable, the air is constantly filled with smoke from forest fires." (July 1868).

"Our women must now be inconvenienced to take their Iaundry to Lake Ljuder because of the lack of water." (August 1868).

"At Öljemåla only one mill can now be used, and that slowly, because of the lack of water." (August 1868).

"This year we must pull up the little barley we have since it is too short to cut." (August 1868).

"When, at the end of the year, we stop for a moment and reflect on bygone days as does the pilgrim when, at his destination, he looks back on his journey, we can clearly recall both gladening occurrences and many distressing and sorrowful. Among the sorrowful we must not pass by the great suffering that afflicted the poor in the scarcity of provisions in the early days of the year. But in all this the Lord has helped, us. The rich gifts that we have received from places both at home and abroad have lessened the suffering considerably. Great efforts have been made by distress committees and almoners to relieve the suffering by arranging work, loans, purchases of seed etc. so necessary for existence until the new crop was ready." (December 1869).

As already mentioned, these crop failures were to be of great importance for the mass emigration from Scandinavia. Many small farmers who by no means belonged to the poorest in the countryside appeared to have lost their faith in the possibility to live and work in their mother-country. ${ }^{4}$

In general both the demographic and the economic development 
in Sweden of the 19th century was rather dynamic. A strong natural increase of the population took place without any real industrialization except for the very last decades of the century. Thus agriculture almost alone had to cope with the problems caused by the strong population increase. Even if the traditional agriculture changed considerably from the late 18th century onwards, the rural pursuits could not properly absorb such a rapidly growing population. An ever-growing share of the people ended up in the rural proletariat despite a strong fragmentarization of the land as well as a substantial clearing of new land occurring at the same time. The only solution would have been to divide the big estates among the new class of poor rural people but of course, a political measure of this kind was far too radical at that time. The Swedish "land question" was never solved.

Far from solving these social problems, the new methods employed by an increasingly commercialized agriculture made the situation even worse. The gap between landowners and others was broadened. It was the gentry and the wealthiest farmers who took advantage of the new possibilities created by commercial farming. The peasantry now became divided into a group of well-to-do households, more of the middle class type, on one hand, and a majority of very small landowners and tenants on the other.

In an area like Långasjö parish there are few traces of expansive, commercial farming. On the other hand the proletarianization was very much present. Even a brief glance at the ownership structure in agriculture reveals this (see Table 1). The fragmentarization of the landed property was apparently very strong during the period 1810-1900. At the same time there was no particular concentration of real estate in the hands of a few owners as was the case in many

Table 1. Farming units in Långasjö parish 1810, 1840, 1865 and 1900. Percentage distribution. Size of cadastrial units (mantal).

\begin{tabular}{lcccccc}
\hline Year & $\begin{array}{c}\text { 1 mantal } \\
\text { and more }\end{array}$ & $\frac{1}{2}$ to 1 & $\frac{1}{8}$ to $\frac{1}{2}$ & $\begin{array}{c}\text { Less than } \\
\text { 雨 }\end{array}$ & Total & $(\mathrm{N})$ \\
\hline 1810 & 0,9 & 3,8 & 82,6 & 12,7 & 100 & 213 \\
1840 & 0,5 & 4,1 & 77,6 & 17,8 & 100 & 219 \\
1865 & 0,4 & 2,0 & 74,1 & 23,5 & 100 & 251 \\
1900 & 0,4 & 3,5 & 65,4 & 30,7 & 100 & 254 \\
\hline
\end{tabular}

Source: Commission Emigration. Report and Supplements. (Emigrationsutredningen) XII tab. D, p. 67. 
other areas of Sweden. It can be noticed that peasanis with farms smaller than $1 / 8$ mantal more or less belonged to the proletariat which otherwise was composed of crofters, cottars and people living-in.

These had lost their ties with land ownership and had to sell their labor, mainly to the more wealthy people in the vicinity but also to more distant employers. In the middle of the 19th century the seasonal migrations from this part of Sweden not only reached the plains of Scania and the Lake Malar Valley of central Sweden, but also Denmark and Germany, where Iarge scale agriculture with hired labor dominated certain regions.

This is exactly the situation in which the emigration alternative appears. For many parishes in southern Småland, emigration would turn out to be most attractive. Sweden's last severe famine was caused by crop failures both in 1867 and 1868, inflicting great suffering on a population that generally lived close to the subsistence level. Considerable evidence points to the fact that many peasants lost faith in their home country and therefore responded strongly to the emigration possibility, a possibility that also meant a new start for maids and farmhands who otherwise had no prospects for the future.

\section{Kinship, Time and Space}

Under the microscope we can follow (see Figure 2) how the mass emigration movement started and developed within a small investigation area between 1850 and the early 1890s. Each small village within the parish is represented by a trajectory on which emigrating individuals, families etc. are attached exactly at the time they moved away. The trajectory also serves as a time axis. The location of the villages and lonely farmsteads can be seen from the map.

Even if Långasjö is situated in a typical high emigration area and the parish itself represents that area as regards external movements, strong differences within the parish borders can be noticed. This is illustrated in the figure as well. The total numbers of emigrating individuals correspond to the areas of the circles in the figure and the frequences are shown within these circles. (The reduction base has been the population size in 1865).

All this information can be found, as mentioned above, in the church records which consist of catechetical examination registers, 
Figure 2a. Family migration over time. (Extract from figure 2.)

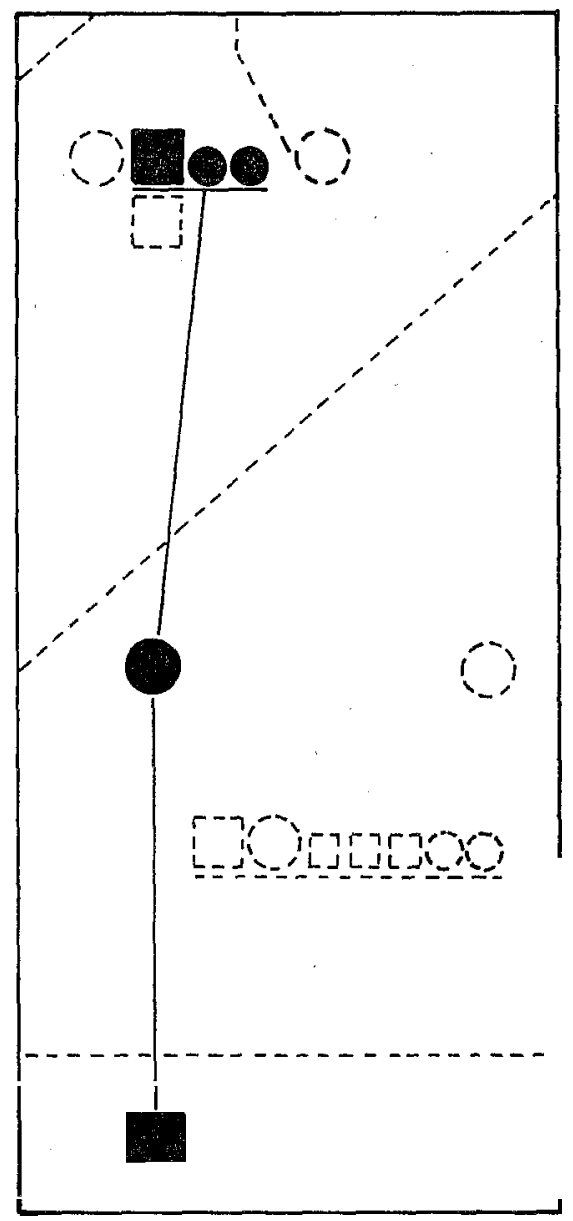

birth and death records as well as in- and out-migration lists. This detailed information system allows us to keep the different families and households together and to examine the kinship net-works in general. Earlier analyses have not been performed by historians but within human genetics (even on historical periods).

In addition, a strong oral tradition about the trans-atlantic emigration from this area still exists. It was tapped in the early 1960s when many emigrants and returning migrants were still alive, as well as other informants. This information has been most useful and not least as regards the light it sheds on the receiving side (where the church records of the Augustana Synod have also been important). 


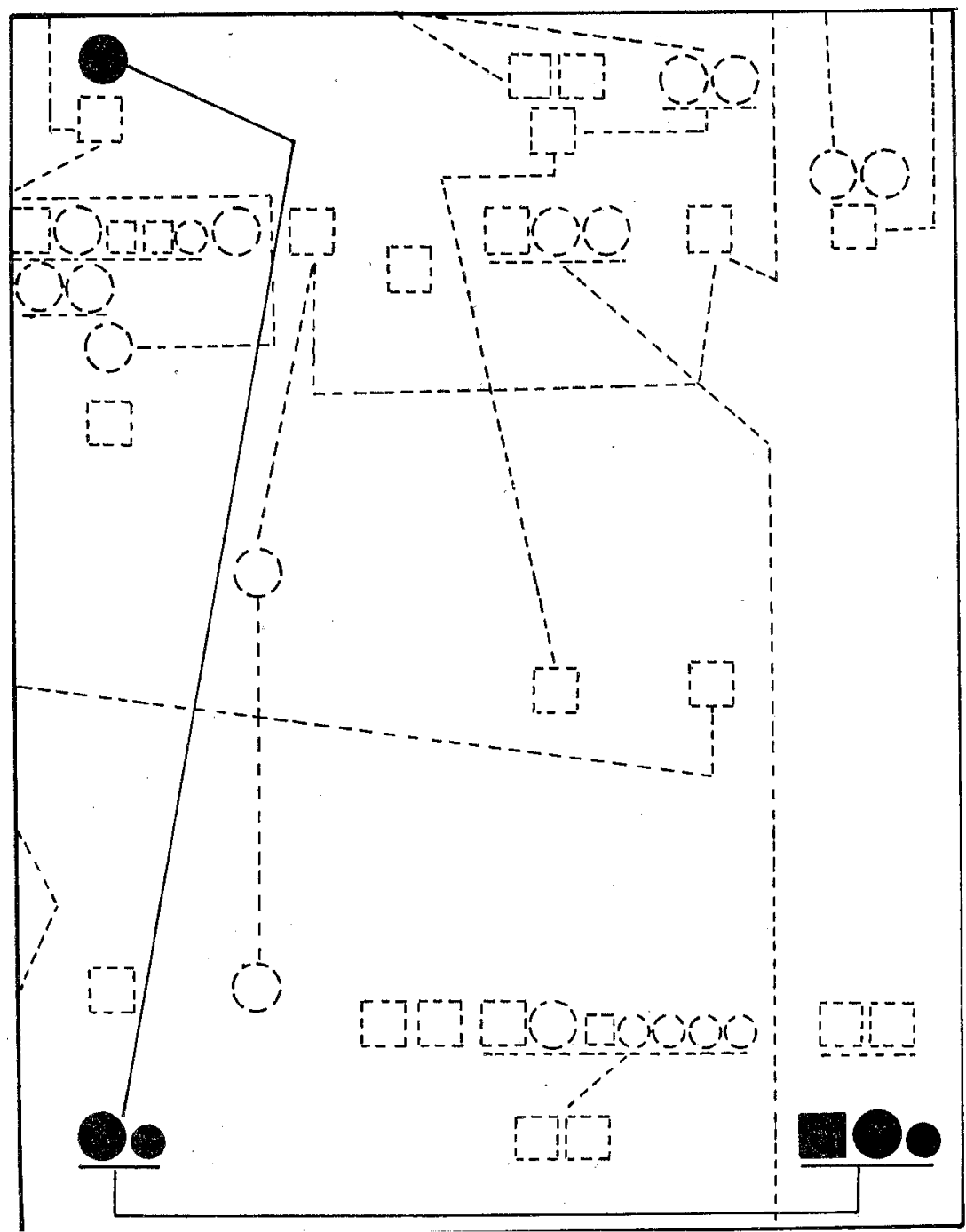

Figure 2b. Intra-parish moves and family emigration. (Extract from figure 2.)

The links between related individuals who have resided in different villages are marked by lines (see Figure 2b) and the family-group on the same spot kept together (underlined) as well as the relations over time (see Figure 2a). This means that the growing emigrational net-work shows family and other relations even though the latter are not thoroughly treated. The movements within the restricted space of the parish are also mirrored to some extent. 
.... 
igure 2. Emigration from Långasjö, 350-1895. Development in time and ace and social times.

surce: En Smålandssocken emigretr. En bok om emigrationen till merika frin Långasjö socken i Kroobergs lan. Växjö 1967; Church xamination Records (husförhörsläng$r)$

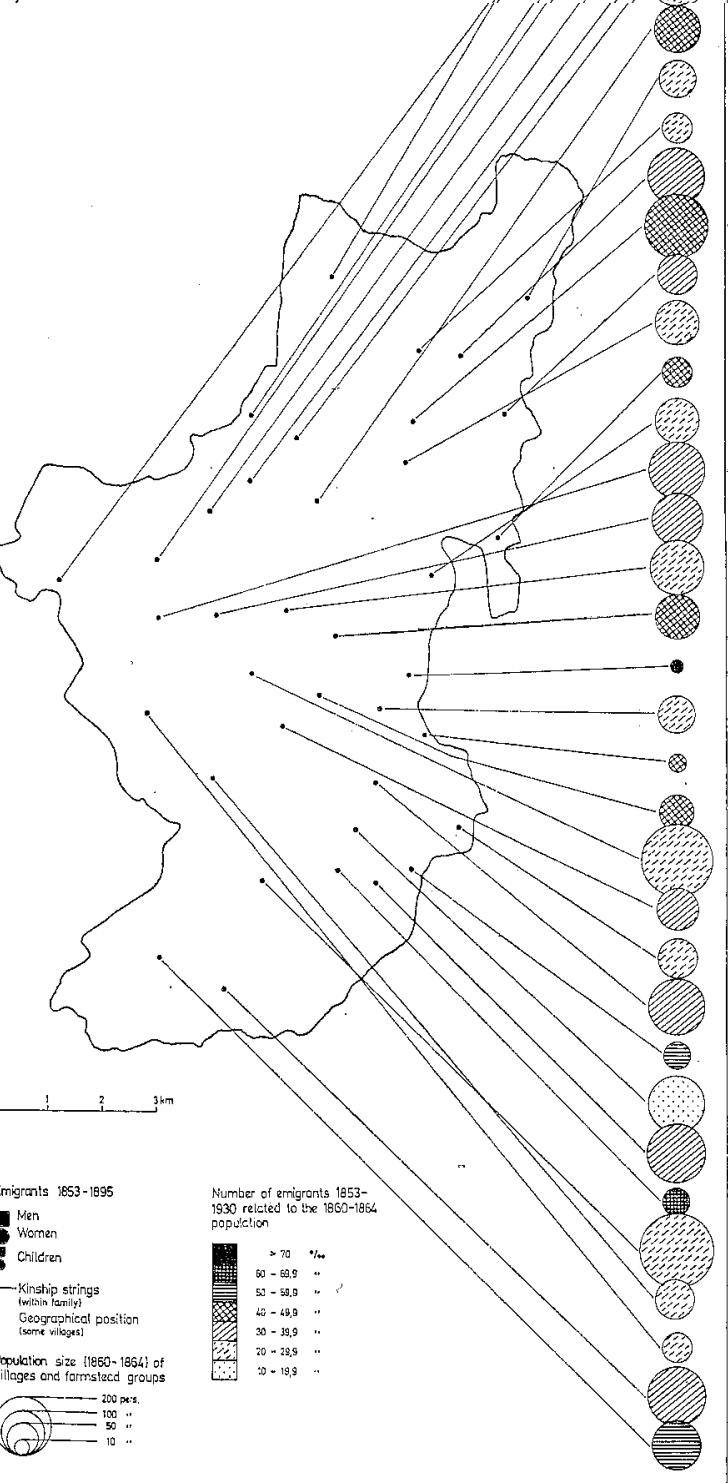

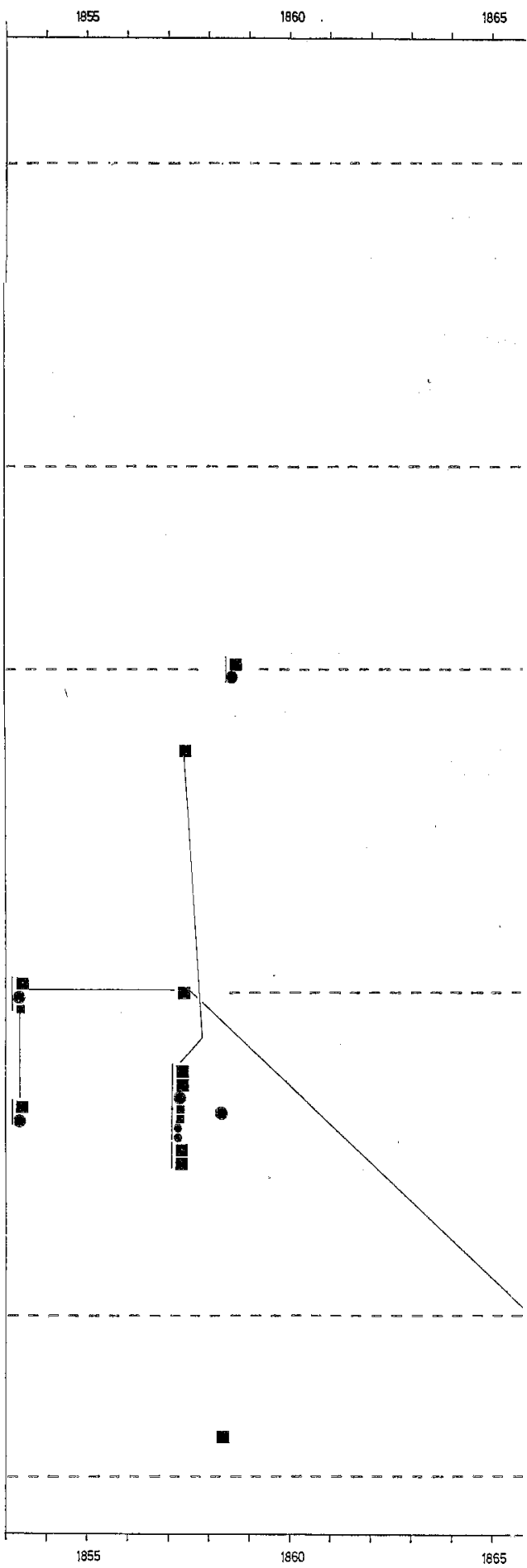




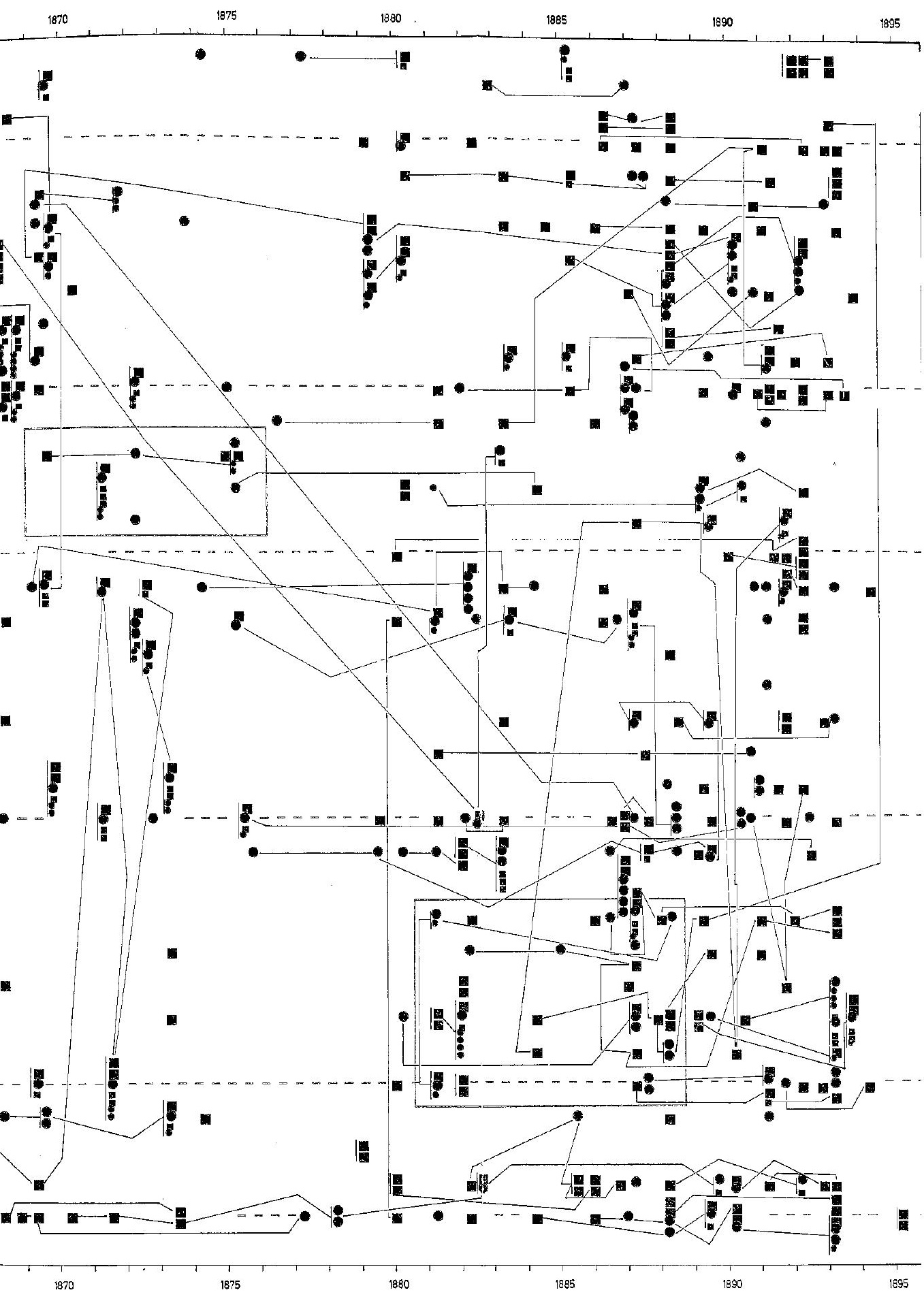




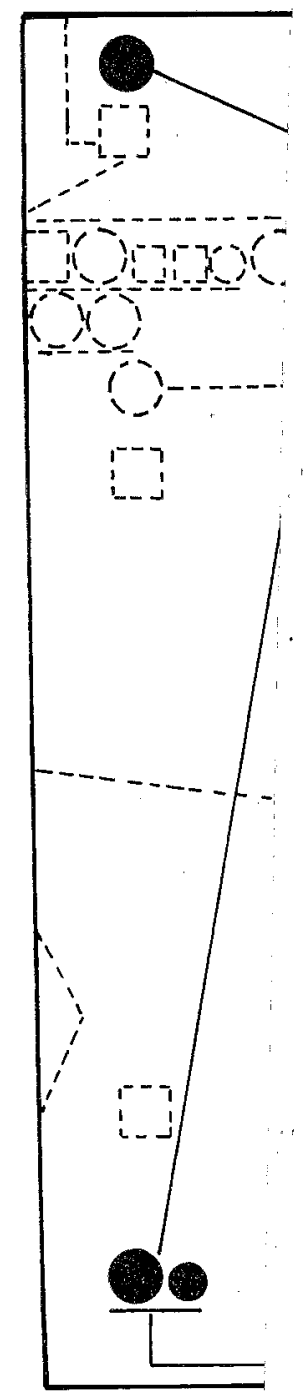

Figure 2b. Intra

The links different villa family-group as the relatic growing emis even though within the re extent. 
Thus we can follow how a family gradually moved away, even though it took 10-15 years before the whole unit had left the country. At that point in time some member of the family may have made the trip across the ocean several times.

Often a part of a family or a household emigrated from one village together with other members of it from other villages or neighboring parishes. As already mentioned, there was also frequently a time lag. The ties between these emigrants are also revealed by the choice of destination in North America. However, these connections and axes were a characteristic feature for both families and units like villages, parishes counties etc. Of course this does not mean that the destinations could not differ within the same European parish. In our investigation area there were marked differences of preference, even if the Chisago Lake district in Minnesota, parts of western Wisconsin and, in the 20th century, British Columbia attracted most emigrants.

For emigrants who were not parts of this cohesive mass movement but travelled alone there was still the possibility of ending up in an area dominated by their own nationality. Such "connecting areas" in the receiving countries were often rather urbanized and their inhabitants must have largely arrived there by stage migration. This fact stresses the ethnic pull forces but it also tends to slightly overemphasize the ties between people of the same European background in the receiving society.

From Figure 2 we can see how some small villages were reached by the mass emigration very early and how they continued to be special recruitment grounds in comparison with other villages which became involved later on or not at all. This tells us something about the mechanisms at work. The spread of the overseas migration was often faciliated by persons who made internal migrations and who belonged to families or villages already participating in the exodus. This means that many persons who are classified as "single" emigrants in the statistical surveys were actually part of a family-or group migration. This shows once more that the time dimension must be kept in mind.

Our emphasis on family and kinship ties must not hide the fact that even contacts within a certain age cohort have been important. School attendance was compulsory from the 1840s which meant that youngsters of the same age were in more or less daily contact at school. Each age group also had to undergo confirmation together at the age of 15 . The enclosures (which were finished just before the 


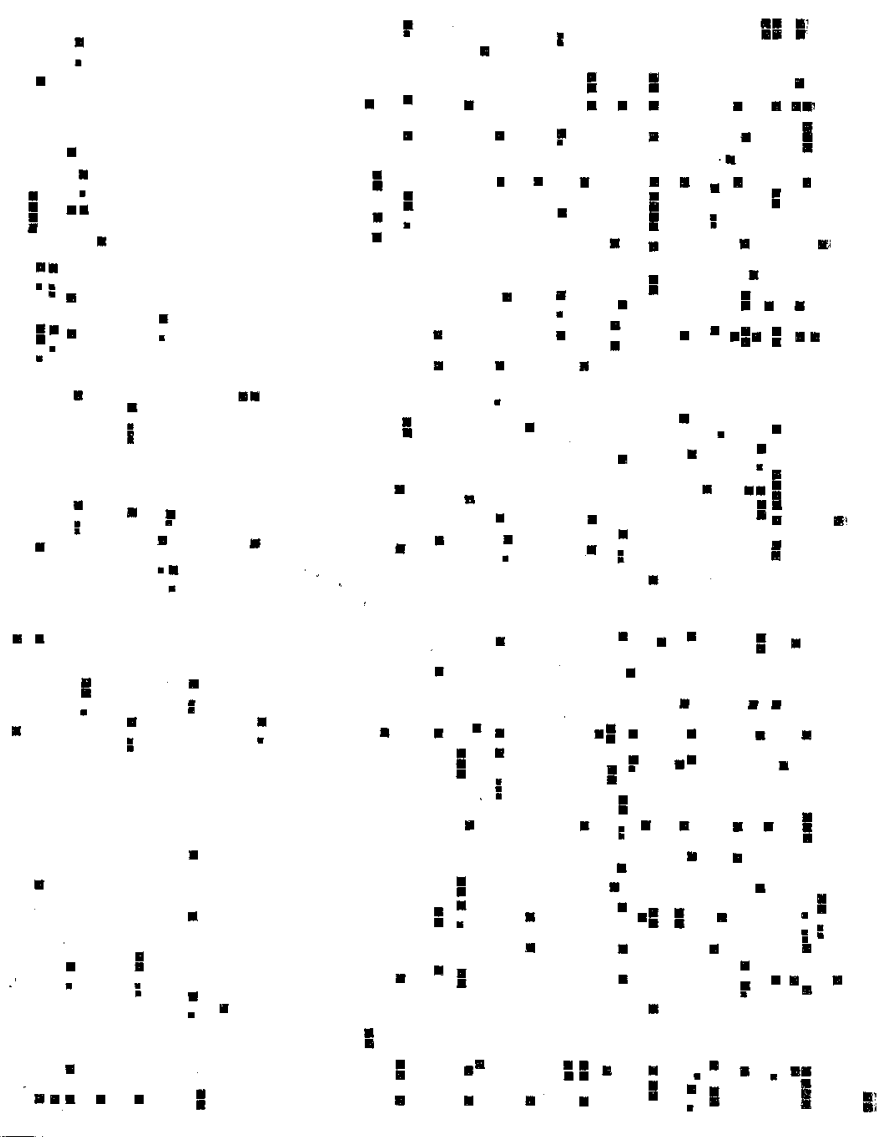

Figure 2c. Emigration of men and boys. (Compare figure 2.)

mass emigration period in Långasjö) and the secularization had started to change the network of social information, but their basic structure must still have been the same. ${ }^{5}$ The age effects on migration will be treated further on.

The figure is broken down even more in Figures 2c and $2 \mathrm{~d}$. It is well known that males dominate the early phase of most mass emigrations, irrespective of whether they are rural or urban. We often separate three different phases as regards the sex ratio between migrants: an early phase when the males dominate almost entirely, a growth phase when women and children enter the picture and finally a saturation phase when the sex ratio is more or less even. The share of the children - which also means the share of families in a narrower sense - is stronger in the growth phase than the saturation phase where labor market mobility tends to dominate. 


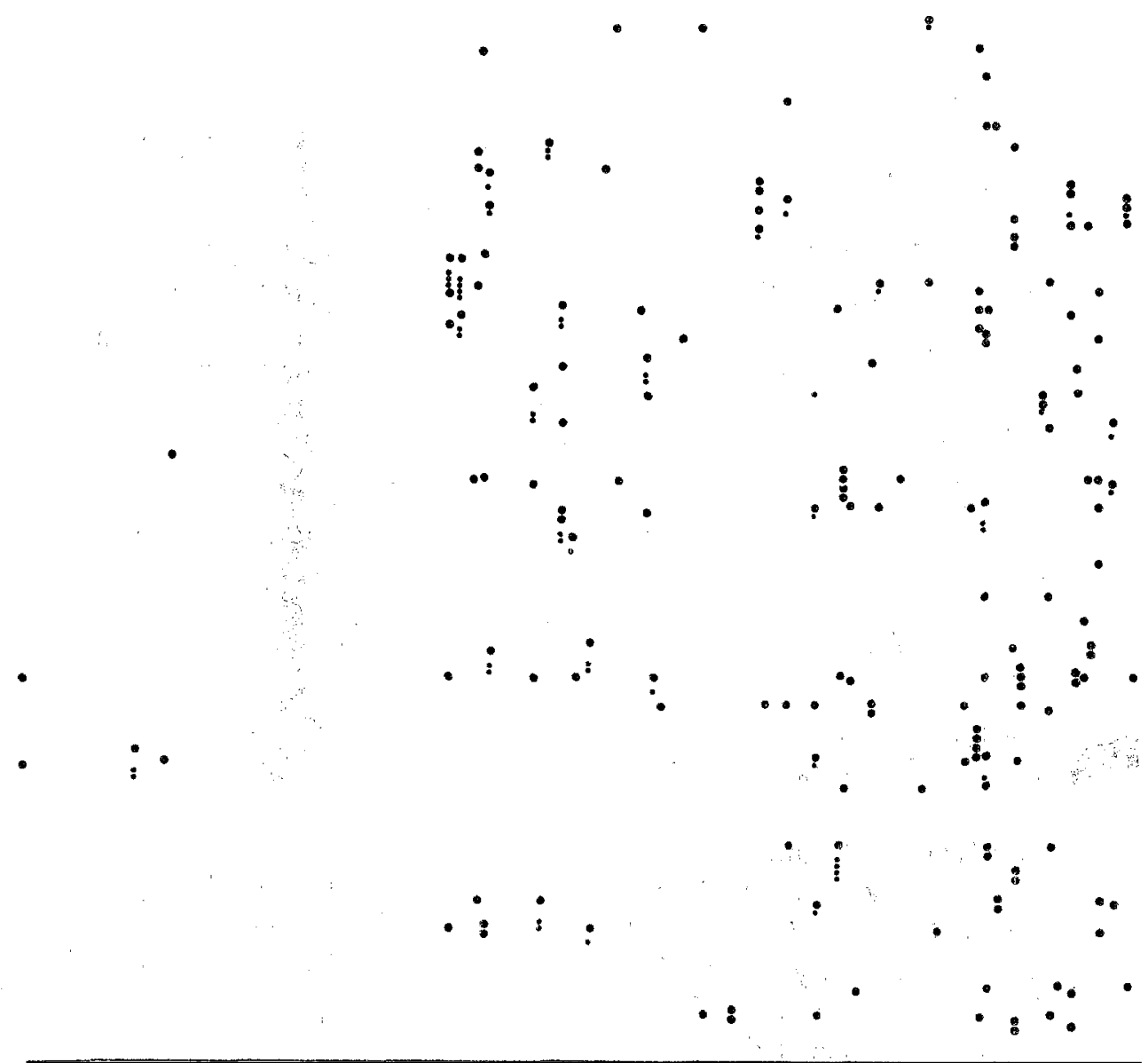

Figure 2d. Emigration of women and girls. (Compare figure 2.)

Some villages within a typical emigration parish or some parishes within a mass emigration district may very well prove to be almost resistent to the emigration offer in question. In these cases the alternative to emigrate has not been attractive (at least not enough to cause action). Similar labor market situations have not caused the same behavior. This is a memento for a simple analysis of economic structures in order to understand migrational movements.

The interplay between population in the receiving and the delivering countries is revealed also in the prepaid ticket system of the mass emigration. This system took advantage $\mathbf{f}$ personal information and persuasion by former emigrants upon their friends and relatives left behind. These were also the target for money remittances in general with their strong pull or persuasive capacity. (The prepaid ticket system contributed of course to keep families 
and the kinship circle together). The large amount of prepaid tickets (sometimes as high as 50-60\% of the total amount of tickets sold) may, however, exaggerate the influence of the pull forces. There was without doubt another reason to buy a ticket paid in advance in the U.S. or Canada and that reason was a technical one. In North America there may have been some competition between the shipping lines even during the periods when cartel agreements in Europe considerably raised the prices. However, the implications of prepaid tickets are still rather evident.

The importance of contacts with neighbors and close relatives in an emigration region will appear also in the timing of movements. The very strong fluctuations of the emigration curve from year to year can only be understood when we consider these changes from a socio-demographic point of view. A close study of Figure 2 will show how the emigration pattern changes from trough to peak years (compare e.g. 1873-78 to 1882,1887 ). In our figure the emigration has been specified for quarters of a year. The trough years are characterized by single emigrants spread out over the sailing season. The recruitment area within the parish has been rather narrow only two family units emigrating during six years (1873-78). The peak years were completely different, showing a strong concentration of the departures in the spring and with a basic feature of group and family emigration. At the same time the number of single migrants increased considerably. In general, the peak years had a strong social density combined with a geographical spread that involved almost all villages of the parish.

\section{The Generation that Refused to Serve as Maids and Farmhands}

A small survey of six villages in Långasjö (which form the trajectories of Figure 2) reveals the demographic situation and development of the period 1865-1895. These were the years of a certain demographic turmoil in the region. The very strong population increase of the first half of the century had come to an end. Internal out-migration, seasonal migrations, and above all trans-oceanic emigration put their stamp on the period. In spite of a substantial natural increase of the population, a decrease of the number of inhabitants can be registered due to the heavy net out-migration. During the thirty years under study, the size of the investigated 
Table 2. The demographic structure of six villages in the years 1865,1881 and 1895 , by size, mothcr's age and total number of household servants.

\begin{tabular}{|c|c|c|c|c|c|c|c|c|c|c|c|c|c|c|c|}
\hline \multirow{2}{*}{$\begin{array}{l}\text { Family- } \\
\text { units } \\
\text { Number of } \\
\text { children }\end{array}$} & Age of & he motl & & & & 1881 & & & & & 1895 & & & & \\
\hline & -24 & $25-29$ & $30-34$ & $35-$ & Total & -24 & $25-29$ & $30-34$ & $35-$ & Total & -24 & $25-29$ & $30-34$ & $35-$ & Total \\
\hline $0-1 \ldots \quad \ldots$ & 9 & 5 & 3 & 18 & 35 & 7 & 2 & - & 26 & 35 & 2 & 2 & 1 & 28 & 33 \\
\hline $2-3 \ldots \quad \ldots$ & 6 & 10 & 7 & 38 & 61 & 5 & 5 & 4 & 31 & 45 & 1 & 5 & 9 & 30 & 45 \\
\hline $4-5 \ldots \quad \ldots$ & - & 2 & 6 & 27 & 35 & 1 & 3 & 8 & 29 & 41 & - & 3 & 5 & 22 & 30 \\
\hline $6-\ldots$ & - & 3 & 2 & 23 & 28 & 1 & - & 3 & 21 & 25 & - & 1 & 5 & 23 & 29 \\
\hline Total .. & 15 & 20 & 18 & 106 & 159 & 14 & 10 & 15 & 107 & 146 & 3 & 11 & 20 & 103 & 137 \\
\hline Maids .. & & & & & 76 & & & & & 23 & & & & & 9 \\
\hline Farmhands & & & & & 42 & & & & & 16 & & & & & 5 \\
\hline Others .. & & & & & 63 & & & & & 27 & & & & & 30 \\
\hline Inhabitants & & & & & 983 & & & & & 857 & & & & & 767 \\
\hline
\end{tabular}

Source: Church Examination Records (husförhörslängder). 
villages decreased by more than 200 persons from 980 to 770 , as well as a certain decrease of the families of the farming population, but the real change will be found among the servants in agriculture. From Table 2 we can see that the maids decreased from 76 to 9 and that the farmhands almost disappeared during the same period, only a handful remaining in 1895.

The information net-work of certain age cohorts was touched upon above. The migration behavior of the young maids and farmhands of our parish substantiates this view. Suddenly the youngsters of the 1870s and 1880s refused employment in the households of the peasants in the vicinity. They all learned about the new possibilities offered by emigration overseas as well as to some extent urban inmigration in Sweden. We suggest that this development was spurred not only by the lack of economic opportunities but also the drive to marry and set up new households. As a matter of fact, the age at marriage, already very high, as well as the low marriage frequency, became even more pronounced during this thirty year period in Långasjö.

\section{The Interplay between Areas of Origin and Destination}

In his doctoral dissertation For Sale - Minnesota, Lars Ljungmark has stressed how important it was for the immigration promotors to establish cooperation with earlier immigrants of a certain nationality. The leading person of Ljungmark's study, Colonel Hans Mattson was fully aware of this mechanism and he even helped his fellow Scandinavian settlers in Minnesota to buy stamps in order to encourage them to write back home thereby inducing new people to leave Scandinavia. Mattson knew very well that the difference between success and failure in his pursuits depended upon how this ethnic cooperation worked out. ${ }^{6}$

This observation is very much in line with our findings and comments above. Ethnic groups as well as nationalities tended to concentrate in areas in the receiving country where others of their kin were already established. This can be seen in great detail when we conduct local studies on a microscale. R. Ostergren investigated immigration to the Chisago Lake district in Minnesota and noticed how concentrated the recruitment field was in Sweden." In fact, Långasjö parish is in the very centre of chis recruitment field (see Figure 3). 


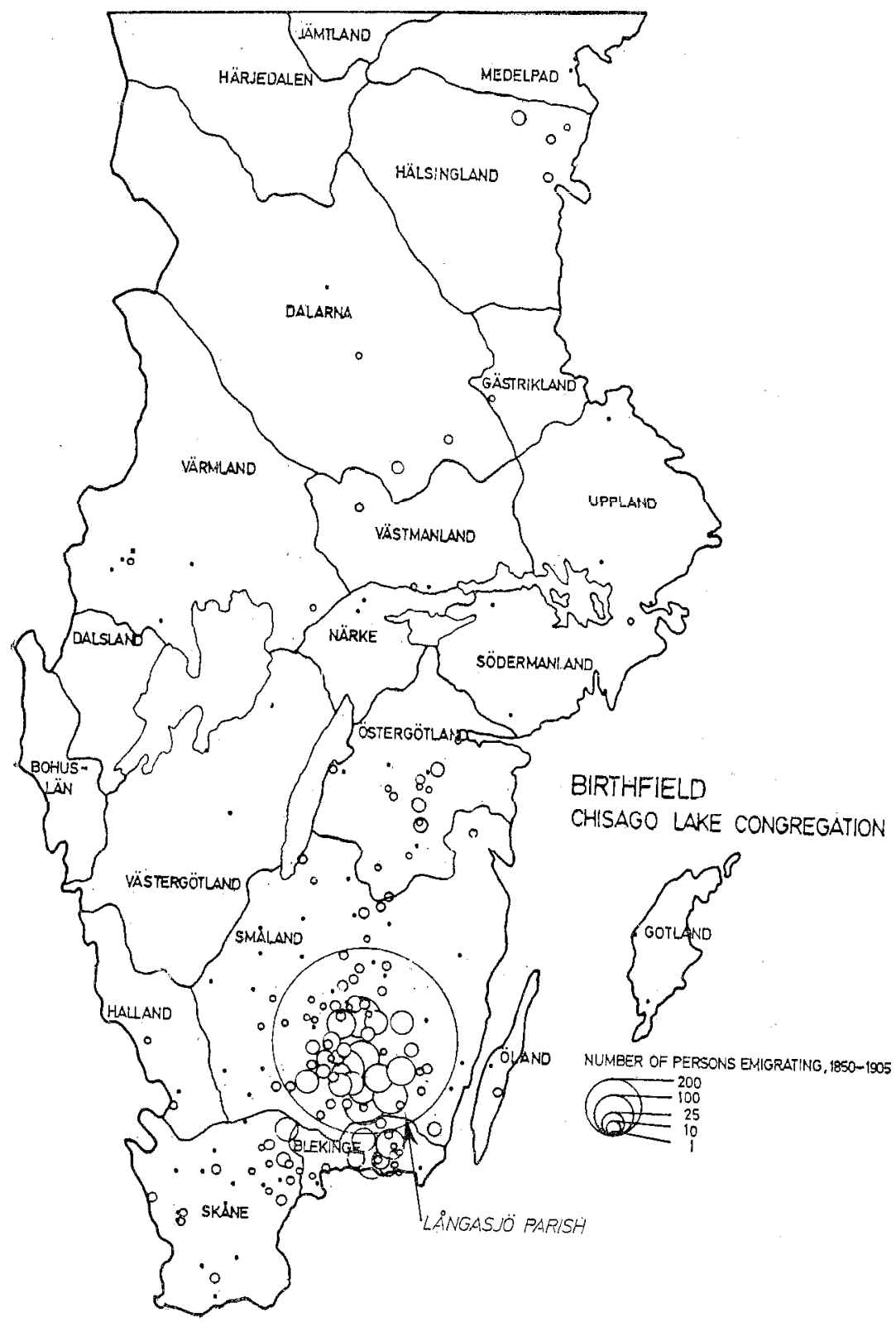

Figure 3. Birth Field. Chisago Lake Congregation, Minnesota.

Source: Robert C. Ostergren, Cultural Homogeneity and Population Stability in Swedish Immigrant Communities. University of Minnesota, Minneapolis 1972. 


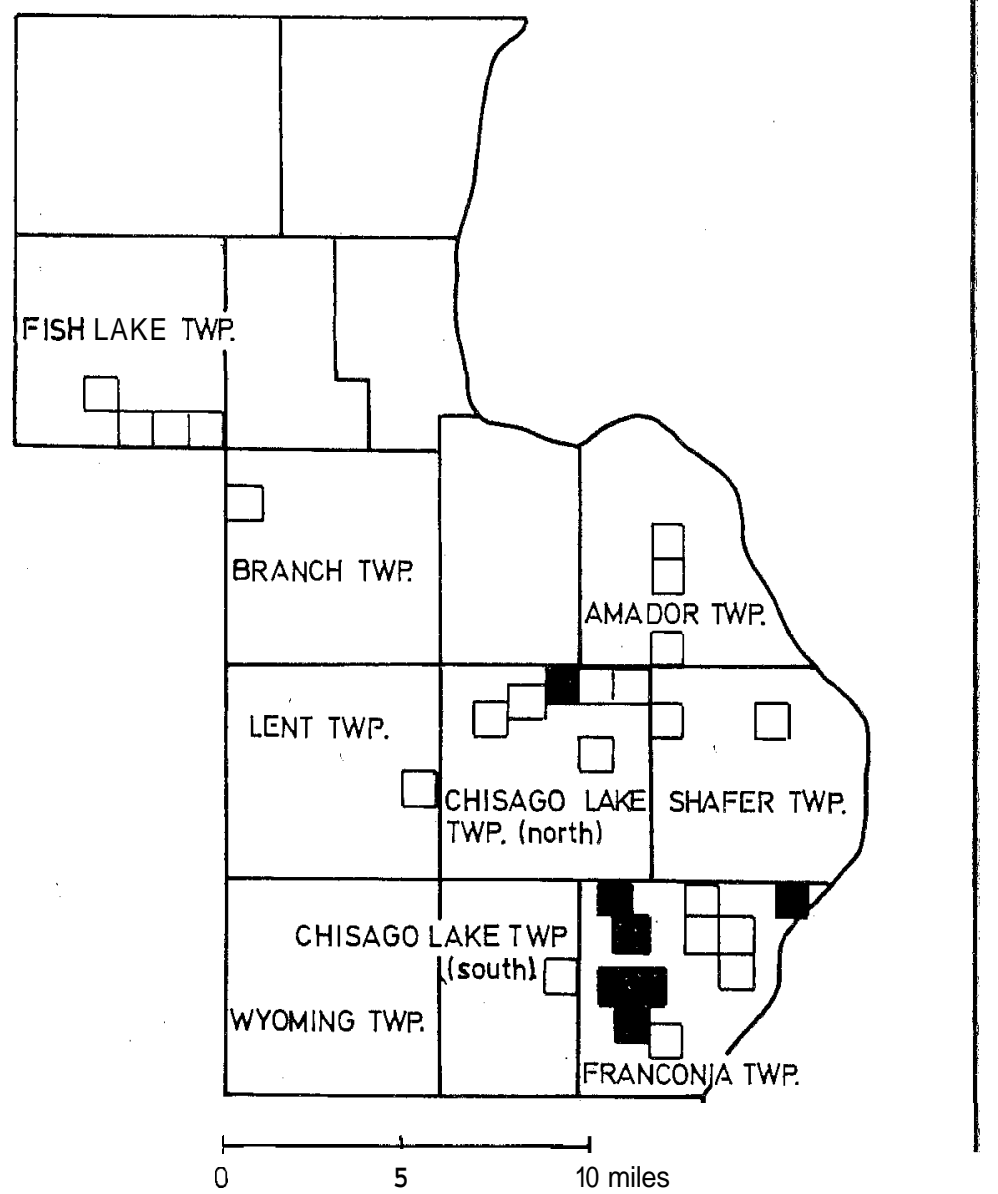

Figure 4. Chisago County 1885. The Abrahamsson settlements.

Source: En Smålandssocken emigrerar. En bok om emigrationen till Amerika från Långasjö socken i Kronobergs län. Vaxjo 1967; Church Examination Records (husförhörslängder). 
In our study of kinship and settlement we can go even further. A small map can show the role of the Långasjö people in the settling of Chisago county up to the mid-1880s. Apparently the Långasjö emigration was channelled to two special townships, Franconia and Chisago Lake North. In Franconia the important factor was one single family and its relatives. Franconia township was settled and dominated by the family of the first emigrant from Liangasjö, Carl Abrabamsson. This fact tells us a lot about the importance of family and kin, as well as ethnic identity, for migration development (see Figure 4$).^{8}$

\section{Concluding remarks}

Within social science scholars have devoted much attention to migrational problems. Their obsession with sophisticated quantitative techniques as well as the scarcity of sources related to the geographical mobility has, however, hampered the development of the research speciality.

To reach new insights and results we have to test other types of analyses and more accurate empirical evidence than statisticians and economists usually treat. Such an approach has been ventured in this essay.

Instead of relying on an aggregate analysis we have tried to trace every emigrating individual or group. Our aim has been to shed light upon the importance of kinship ties for the birth and development of migrational streams. Hence we have studied the strong selfgenerating capacity of most voluntary human emigrations. To that end a special scheme of analysis has been developed.

\section{NOTES}

1 Migration is a subject that is treated from an inter-disciplinary aspect and from different angles. See for example, William Petersen, Population, Second ed., London 1969; J. J. Mangalam, Human Migration - A Guide to Migration. Literature in English 1955-62, Lexington 1968; Dorothy Swaine Thomas, Social and Economic Aspects of Swedish Population Movements 1750-1933, New York 1941; Harald Runblom and Hans Norman (eds.), From Sweden to America. A History of the Migration. Uppsala 1976; Encyclopedia of Social Science, I-XVII, 1968.

2 The material for this paper is taken from En Smâlandssocken emigrerar. En bok om emigrationen till Amerika frdn Långasjö socken $i$ Kronobergs län (Långasjö emigrationscirkel), Växjö 1967; Husförrhörslängder (Parish Register of Cate- 
chetical Examinations) for Långasjö socken 1850-1900; Emigrationsutredningen. Betankande och bilagor I-XX (Commission on Emigration. Report and Supplements), Stockholm 1908-13.

3 The reliability of Swedish church records is analysed by, for example, LarsGöran Tedebrand, "Sources for the History of Swedish Emigration" in Runblom and Norman, Op. cit., pp. 76-93.

4 Dagbok fir Sven Samuelsson, Akerby Ljuder, åren 1837-1920, (Emigrantinstitutet, Växjö).

5 Cf. Holger Wester, Innovationer $i$ befolkningsrirligheten. En studie av spridningsförlopp $i$ befolkningsrörligheten utgdende från Petalax socken $i$ Osterbotten, Stockholm 1977.

6 Lars Ljungmark, For Sale - Minnesota. Organized Promotion of Scandinavian Immigration 1866-1873, Stockholm 1971; Cf. Helge Nelson, The Srevedes and the Swedish Settlements in North America, Vol. I-II, Lund 1943; Hans Norman, Från Bergslagen till Nordamerika. Studier $i$ migrationsmonster, social rörlighet och demografisk struktur med utgångspunkt från Örebro lan 1851-1915, Uppsala 1974, pp. 211-287 ;Jan Redin, "Långasjöborna i Chisago County." in En Smålandssocken ernigrerar, Vaxjo 1967; John G. Rice, Pattern of Ethnicity in a Minnesota County 1880-1905 (Geographical Reports, No. 4, Dept. of Geography, University of Umeå.) Umeå 1973.

7 Robert C. Ostergren, Cultural Homogeneity and Population Stability in Swedish Immigrant Communities, (Unpublished Paper, University of Minnesota) Minneapolis 1972.

8 The amalgamating effect of family and kinship in different migrational settings has also been noticed by Philip J. Greven, Jr, Four Generations: Population, Land, and Family in Colonial Andover, Massachussetts. Cornell University Press. Ithaca and London 1972. Esp. Chapter 8. 


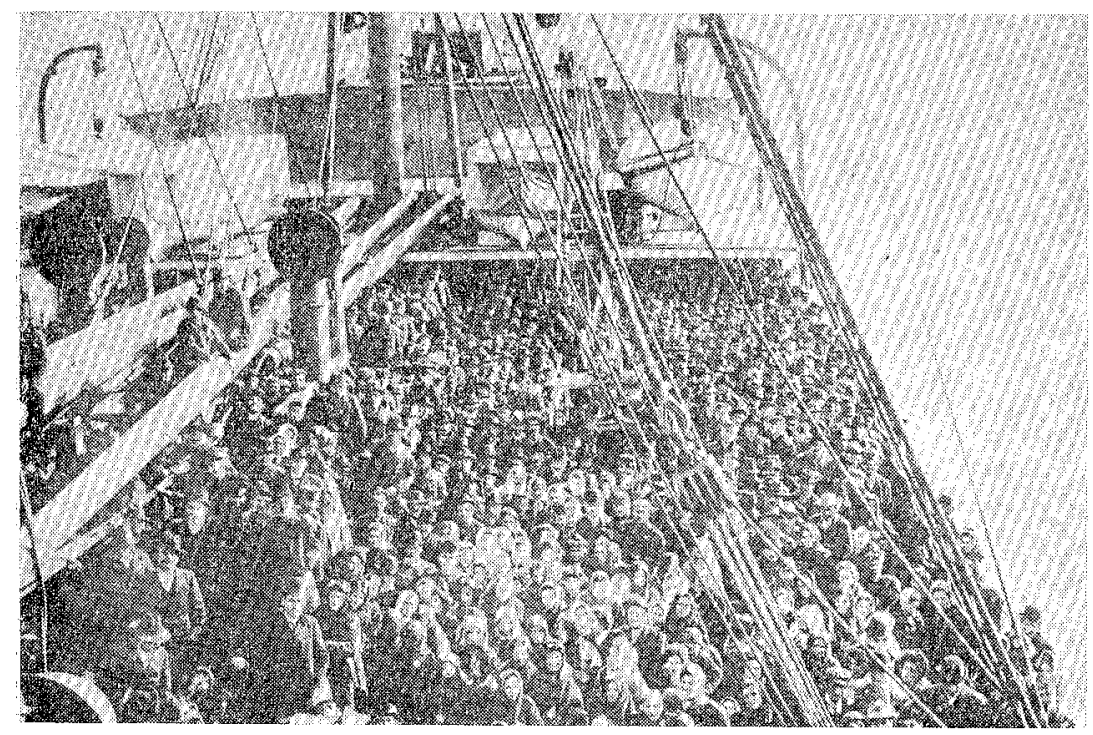

Emigrants at sea in tlie early 1900s. Emigrantinstitutet, Växjö.

Improved communications, on land and at sea, were a decisive factor for mass emigration.

An American express train, 1866. Emigrantinstitutet, Växjö.

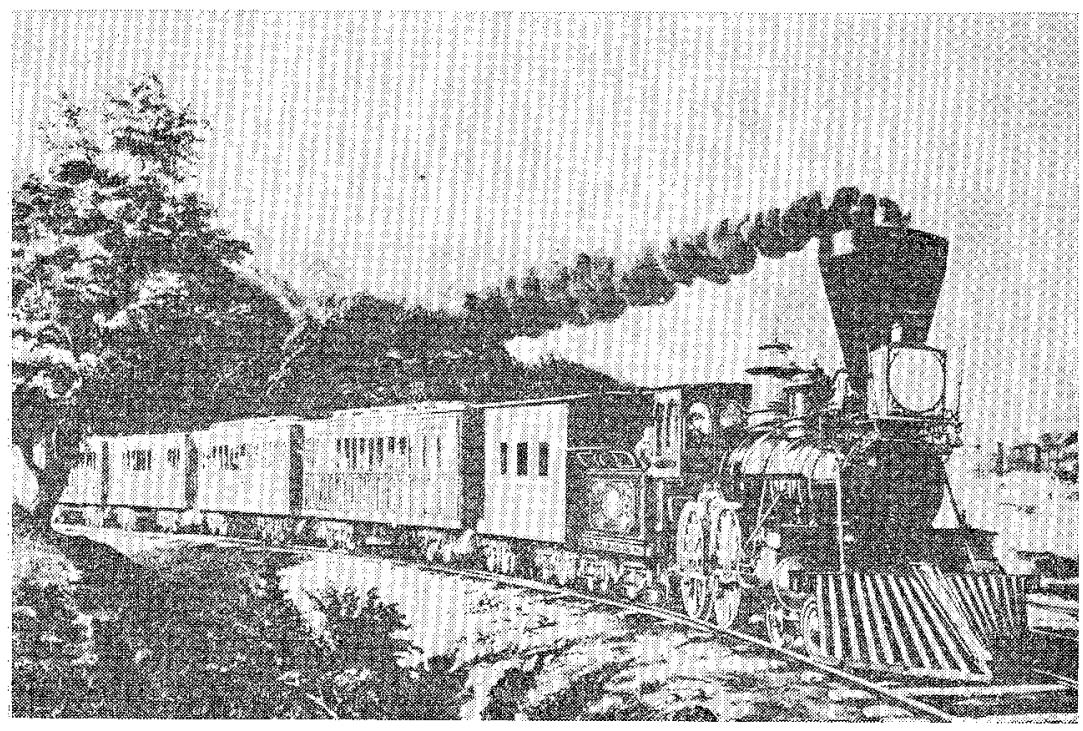




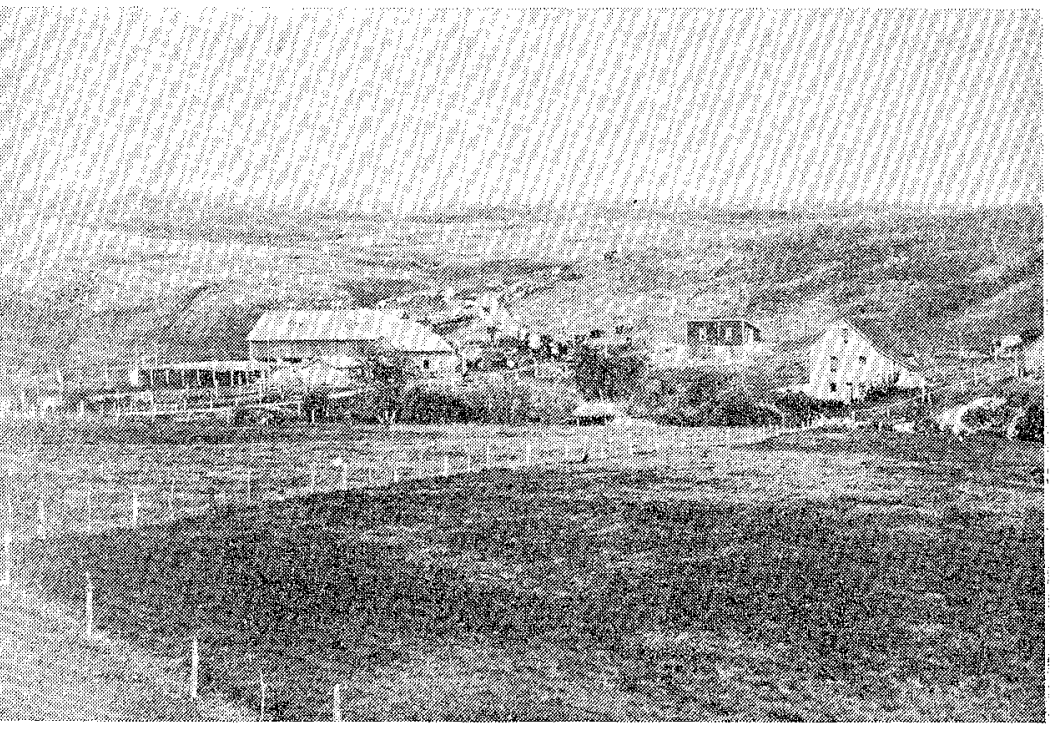

farm in the neighbourhood of Belt, Montana. Emigrantinstitutet, Växjö.

he dream of owning a farm in America could not always be dlfilled...

anadian log cabin in the 1920s. Emigrantinstitutet, Växjö

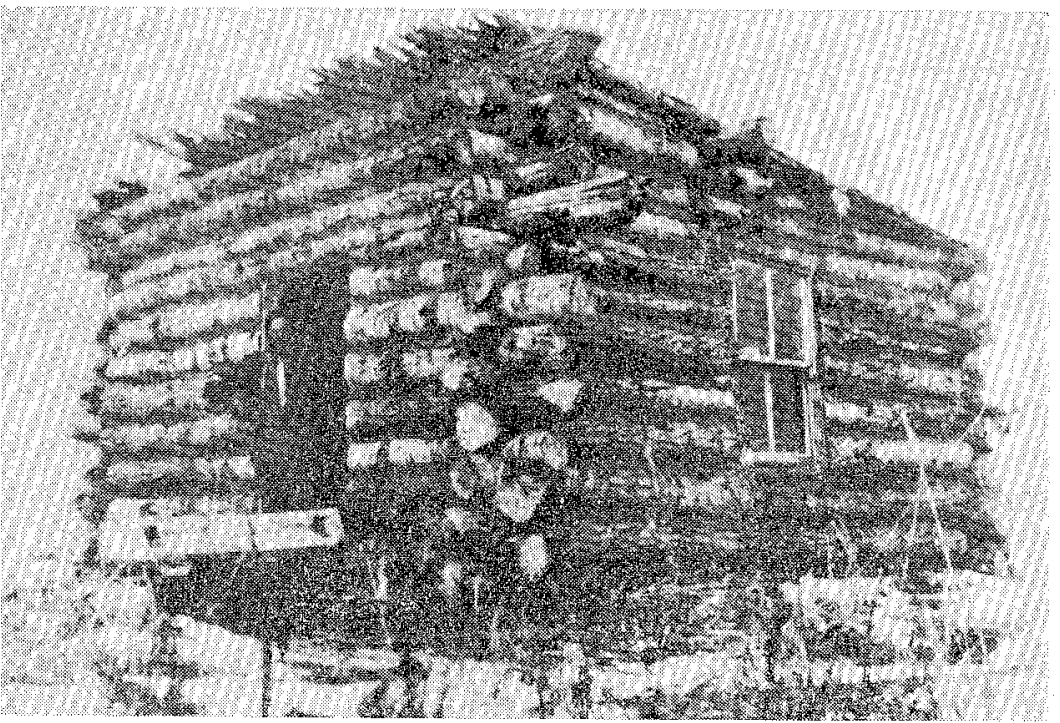




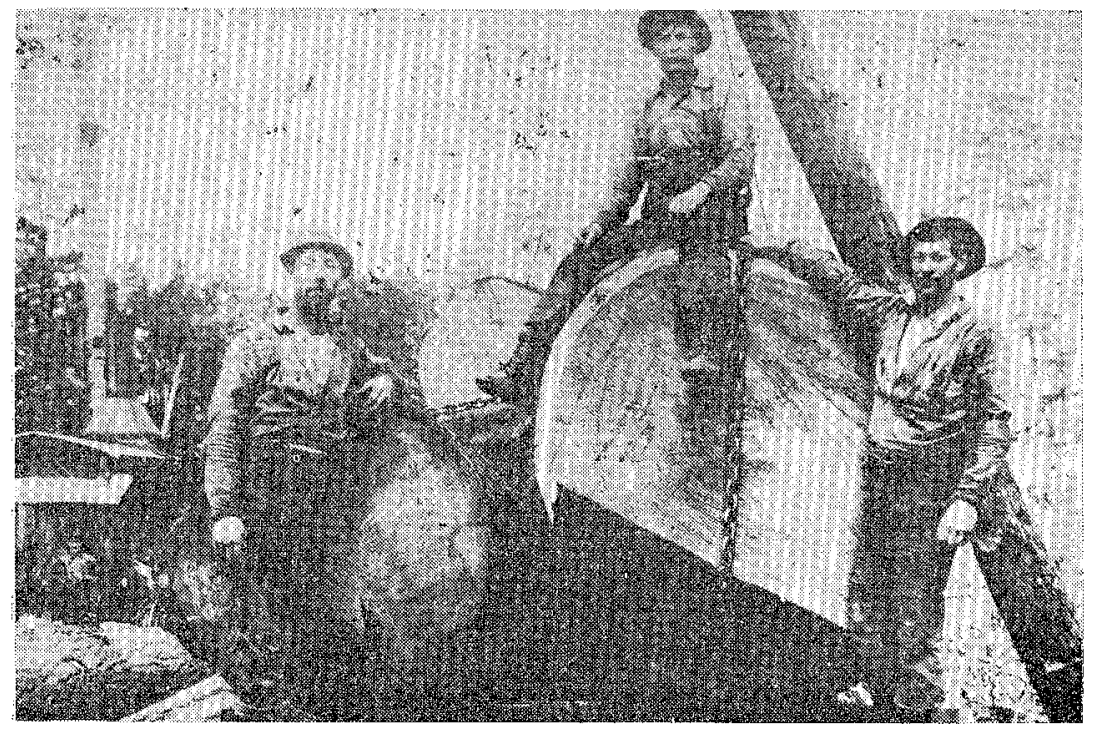

Lumberjacks in America. Emigrantinstitutet, Vaxjo.

... and many emigrants instead found work in the expanding American industry.

Automobile production at Figland Park. Emigrantinstitutet, Växjö.

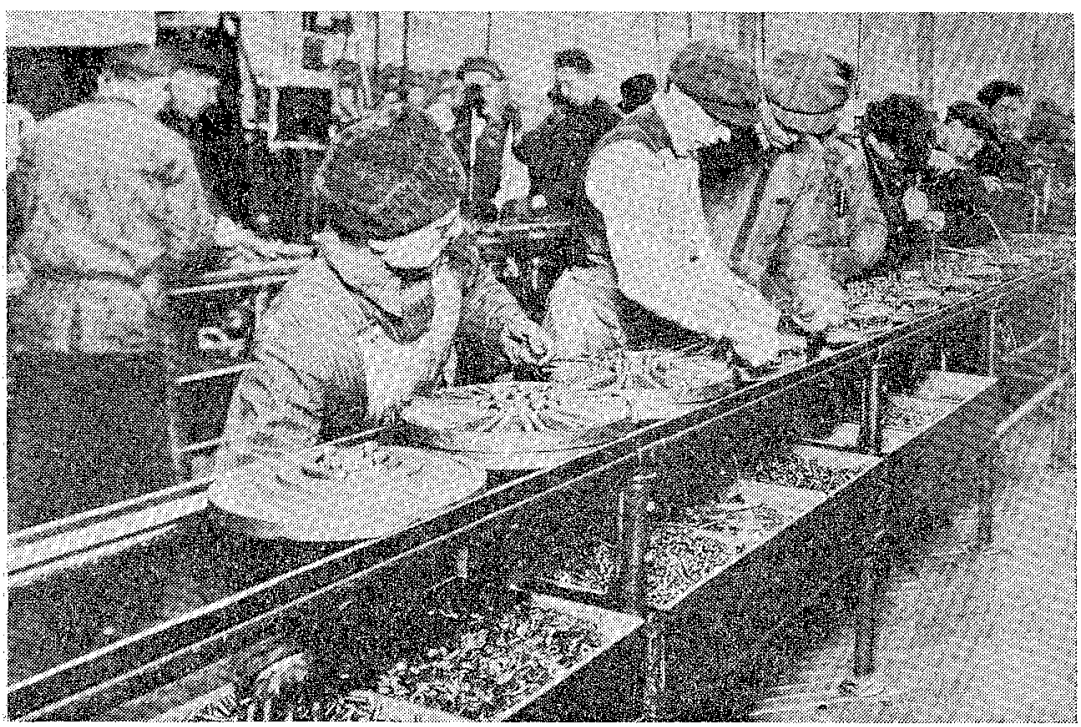




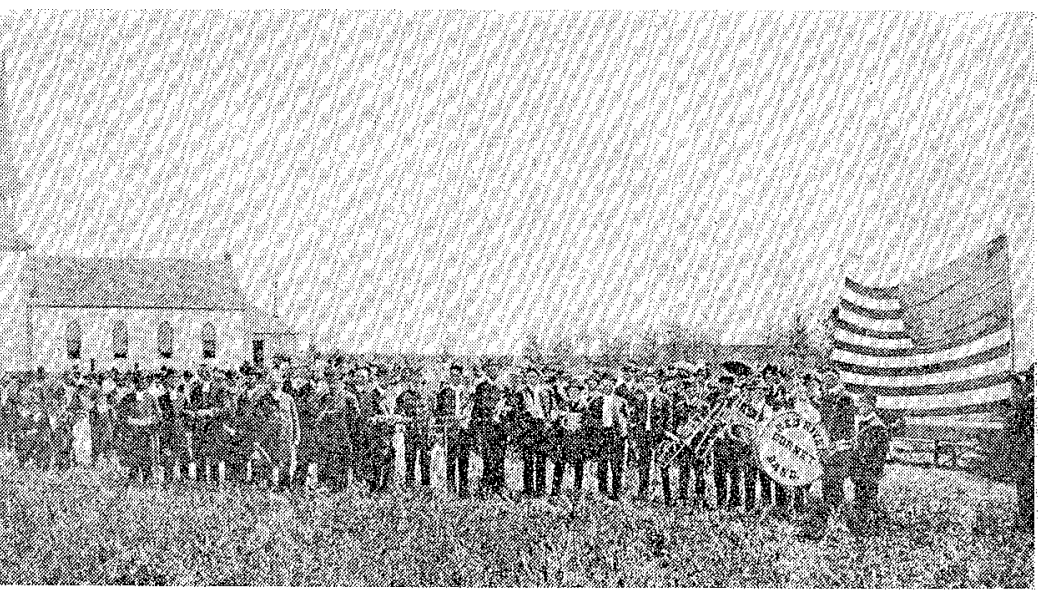

he Swedish Evangelican Lutheran Red River community in Minnesota, 1906. nigrantinstitutet, Vaxjo

he formation of church communities and societies in their new me country was of great importance for preserving the unity ithin various ethnic groups.

he Smolan Brass Band, Kansas, 1909. Emigrantinstitutet, Vaxjo.

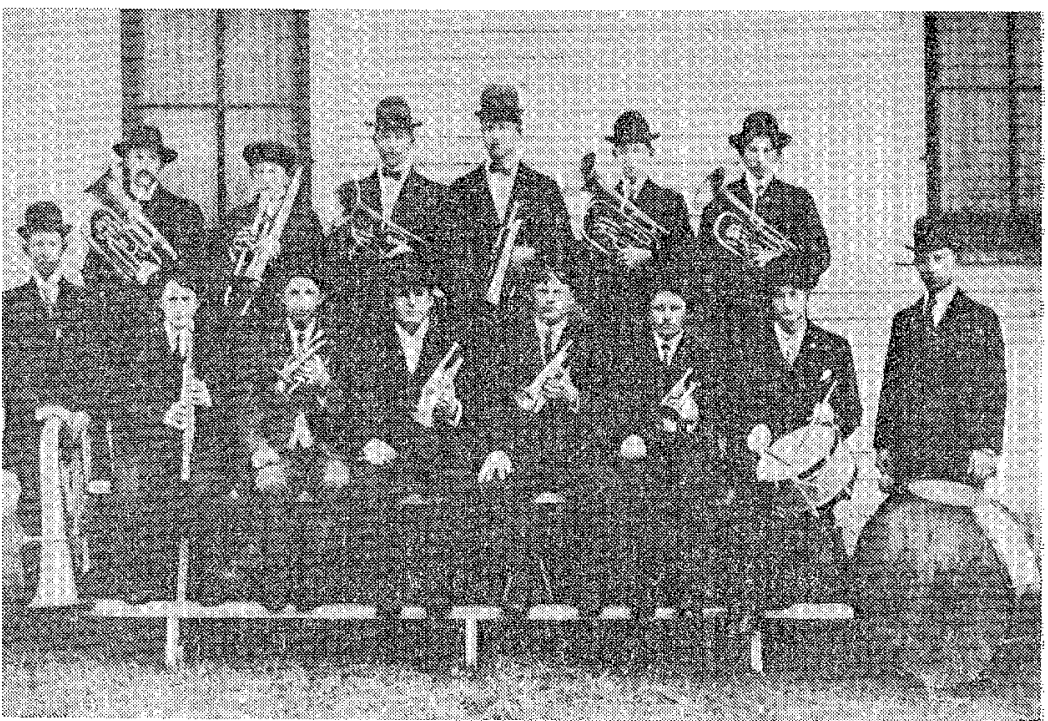

